\title{
Prison Radicalization in Bangladesh Present Scenario and Threats
}

\author{
Md. Mostafizur Rahaman \\ Program Manager CAMPE \& \\ Associate Professor (Adjunct), Development Studies Department \\ North South University, Dhaka, Bangladesh \\ smostafiz_r@yahoo.com
}

\begin{abstract}
Prison radicalization is a global concern particularly in the moderate Muslim countries those are under threat for violent extremism by Islamist militant. Though the aim of prison is to protect society by confining offenders in facilities that are supposedly safe, humane and secure and to ensure that offenders are actively participating in programs that will assist them in becoming law abiding citizens when they return to their communities. But prison settings present both risks and opportunities with respect to violent extremist offenders. Poorly managed detention facilities of any types could become potent incubators of radicalization though it is not the only place where violent extremist radicalization occurs. Bangladesh is one of the countries which is facing threat by Islamist militant. The law enforcement situation, democratic practice, injustice and discrimination among the different classes are setting fuel to become people radicalize. The prison situation of Bangladesh is very worse and it may become a hub for recruitment and brain wash place for Islamist militant. The key objective of the study is to assess the realities of prison radicalization in Bangladesh and the effectiveness of deradicalization programs. Based on the objectives the study has designed on qualitative approach. The data was collected via using a semi structured questionnaire exploring the concept of radicalization, prison radicalization, process, key factors and ways to prevention from both from primary and secondary sources. The paper will give a real scenario of prison of Bangladesh, problems, management system of captured Islamist militants and interventions for deradicalization.
\end{abstract}


KEY WORDS: Bangladesh, Islam, Islamist, Prison, Radicalization, Violent extremism, law enforcement.

\section{Prison Radicalization}

Prison aims to protect society by confining offenders in facilities that are supposedly safe, humane and secure and to ensure that offenders are actively participating in programs that will assist them in becoming law abiding citizens when they return to their communities. But poorly managed prison of any type could become potent incubators of radicalization. It is not the only place where violent extremist radicalization occurs. Prisons have on many occasions been acted through individual deradicalization and disengagement and contributed towards reversing the process of radicalizations and undermined terrorist campaign on the outside.

Prisons are often said to be the breeding grounds for radicalization. Throughout history, prisons have served as recruitment centers and headquarters for ideological extremists, where they used their time behind bars to develop extremist philosophies and recruit others into their mode of thinking (Golam B, 2010). It plays an enormous role in case of radical and militant movement in the modern period.

There has also been a sharp rise in popularity of Islamic conversion in prisons, which is worth noting. Many of these conversions have a positive effect with inmates generally looking for a new direction in life. However, there has also been a rise in radical young inmates ganging together, idolizing terrorism and viewing terrorist association (real or imagined) as status. In the U.S. in 2006 there were 162,000 prisoners incarcerated in the federal prison system and six percent of the population seeking Islamic religious services. The number of converts to Islam in prison is estimated to be between 300,000 and 350,000 each year. At present prison radicalization has already spread out in many countries e.g. Afghanistan, Algeria, Egypt, France, Indonesia, Israel, Jordan, Morocco, Netherlands, Pakistan, Philippines, Saudi- Arabia, Singapore, Spain, UK, USA, Yemen etc.

One of the examples of prison radicalization is Abu Muhammad Al-Maqdisi who is one of the most important living Jihadi ideologues. He was imprisoned in Jordan in 1995 for 15 years and during his time in prison he sought out new recruits. His most famous recruit in prison was Abu Musab Al Zarqawi who became the leader of $\mathrm{Al}$ Qaeda in Iraq. Another case - Jail to Jihad of Indonesia highlights it duly. Afif was an inmate in a high-security Indonesian jail when he transformed from aspiring radical Islamist to soldier for Islamic State (ISIS), ready to sacrifice his life for a group based thousands of miles away in the Middle East. Afif's graduation from jailbird to jihadist 
shines a light on a (Indonesian) prison system where staff shortages, overcrowding and corruption have allowed extremists to mingle and emerge as determined killers in the name of Islam (Reuters 2016).

\section{Radicalization in Bangladesh}

The trend of radicalization in Bangladesh does not have a long historical precedent. A form of radicalization was rooted after the changes in political situation in 1975. Successive governments after ' 75 tried to make civilian alliance under a military auspicious. Migrant workers particularly who went to the Middle East were exposed to a particular of Islam, namely Wababi Majbab and more conservative Arab culture were another factor of this kind of Islamization in Bangladesh. Flow of money from Middle East in disguise of different aid or charity played an important role to strengthen different Islamic political parties.

The history of violent Islamist religious extremism goes back to the mid-1990s. First generation extremists were the Soviet-Afghan war returnee and created Harkat-ulJihad al-Islam (HUJI) in Bangladesh. The second generation appeared in 1996 with the advance of the organization named 'Qital Fi-Sabilillah'. This organization transformed in to 'Jamayat-ul-Mujahedin' known as JMB in 1998. It was deeply connected with HUJI. The third generation of Islamic radicalization started from 2001, through the group known as Hizbut Tahrir. It had a direct linkage with an international movement on-going in other countries. The fourth generation commenced in 2007 through the group known as Jamatul Muslemin which later began to function as'Ansarulah Bangla Team. They were influenced by Anwar Alwaki and presently claim to represent AlQaida at Bangladesh with the name Ansar Al-Islam. Presently Bangladesh is going through the fifth generation of this trend. Emergence of ISIS has hatched the fifth generation. This generation feels affiliated with the ideology of ISIS. In 2015, the $\mathrm{JMB}$ was divided into two groups, one was the older JMB and the new one who left the JMB for some ideological reason is known as Neo-JMB. This new group claims that they belong to the Bangladesh chapter of IS.

The fifth generation is an educated young group, to be pursuing their objective of establishing an Islamic state in Bangladesh (Riaz 2016). Last year they led the most unprecedented savagery in Bangladesh during the month of holy Ramadan in 2016. That brutal incidence was realized in a restaurant at Dhaka by a group of 7 young attackers which extinguished the lives of 29 people, including 20 hostages (18 foreigners and 2 locals). All of the attackers were also killed during the rescue operation conducted by the Bangladesh Army. It was found that all of the attackers 
who were radicalized (to be jihadis) were educated and were from well to do families. The flow chart of militant activities could have described as

Liberal Islam $\longrightarrow$ Fundamental Islam $\longrightarrow$ Radical Islam $\rightarrow$ Violent Islam

\section{Methodology}

The required data was collected both from primary and secondary sources. The major methods of data collection were existing research reports, program reports, publications relevant to prison radicalization and extremist violation in Bangladesh and countries like Bangladesh, Key Informant Interviews and Case Study. The key informants were selected from the different governmental and non-government organizations i.e. government officials who were directly or indirectly linked with prison, former Inspector General (IG) of Prisons, Deputy Inspector General (DIG) of Prisons, and security analysts, lawyers (those who deal with prison related issues), academics etc. The data was also collected by using a semi-structured questionnaire exploring the concept of radicalization, prison radicalization, process, key factors and ways to prevention.

\section{Prison of Bangladesh}

The prison system is one of the largest citizen welfare systems in Bangladesh, being managed by the Department of Prisons under Ministry of Home Affairs. The prison system follows a legal basis from the British colonial rulers framed in the $19^{\text {th }}$ century (1894). It has altogether 9027 staff across the country including in 68 prison establishments - 13 Central Jails and 55 District Jails (Bangladesh Prison 2016). Though most of the prison population is Muslims, no post of Official Imam in Prison mosque was found in the organogram of Department of Prisons. Prison officers and staff are not recruited with appropriate skills or trained adequately to encourage reform though trainings are provided to them through Prison Training Institute and Prison Training Academy.

\section{Law Enforcement and Extreme Violence in Bangladesh}

Despite relative peace on the streets, the country was yet to emerge from its cycle of political violence. The government's heavy-handed, repressive response to challenges from the political opposition and to national security from extremists provokes violent 
counter-responses, aggravating pressure on police and judiciary which is undermining rather than buttressing the rule of law. A resurgent extremist threat, symbolized by the killing of secular bloggers and foreigners and attacks on religious minorities in 2015 and in April 2016, adds to the security challenges. (ICG 2016)

A staggering 5300 people, including 85 members of suspected militants and banned militant outfit Jamáatul Mujahideen Bangladesh (JMB) while one of Ansarullah Bangla Team (ABT) were arrested in the first 3 days of a week-long special crackdown operated (June 2017) throughout the country in the wake of a string of targeted killings, especially the murder of Superintendent of Police Babul Akter's wife in Chittagong. Although the nationwide operation was to deal with militants and other criminals, a number of BNP-Jamaat activists were among the arrestees. (Daily star 2016)

\section{Vulnerability of Prison in Bangladesh}

Delays in Criminal Justice System Proceedings 'The criminal justice system in Bangladesh operates with wide-ranging problems, including a lack of cooperation between the different criminal justice bodies and has resulted in an enormous backlog of cases in the courts, while the prisons remain severely overcrowded. Consequently, countless pre-trial detainees, most of them very poor, spend long periods in prisons waiting for their cases to be resolved.

A report referred to Judge Abu Ahmed Jamadar, Joint Secretary (Opinion) in the Law and Justice Division of the Bangladesh Ministry of Law, Justice and Parliamentary Affairs (MoLJPA) who made following comment about the dire situation of Bangladesh's criminal justice system. 'In my five years at the Ministry,'I have watched the court case load increase day by day. At the end of 2011, there were 2.13 million cases pending before the Bangladesh Supreme Court and subordinate courts; at the end of 2012, that number rose to 2.45 million; end of 2013, it was 2.8 million' (GIZ 2016). Irregularity in Prisons: Corruption is also alleged to be rife among criminal-justice agencies. The 'briefing session' in Amdanikhana, a hall room where all the newly admitted prisoners are rounded up for it and to be allotted to the specific wards and cells is the "reception process" in prisons right from the start, according to an inmate who spent three terrible months in Dhaka Central Jail.

However, one needs to send taka 4,000 inside that jail so that the recipient gets taka 3,600 . The taka 400 is the commission for the jail gate staff. In this way a prisoner in Dhaka Central Jail has to spend a minimum of around taka 30,000 a month for food and other services which the state is supposed to provide for free. (Daily Star 2016) 
According to a former inmate, they can get any undue and illegal privileges by bribing the guards.' For example, using mobile phone inside the prison or getting alcohol or narcotics, like marijuana or methamphetamines are not a problem at all' Availability of narcotics inside the jail has been a very old and well-known subject.

Overcrowding in Prisons: Prisons in Bangladesh are so overcrowded that" 200 prisoners could be observed to be sleeping in a 40 square meter cell". There is even a news report that 65 prisoners were crammed into a room suitable for 20 at most. They had no place for sleeping. They could only sit with their legs almost touching their chests. This massive overcrowding makes it impossible for Bangladesh prisons to deliver UN defined minimum standards of adequate light, air, decency and privacy (GIZ, 2011). The number of prisoners in all prisons of Bangladesh (as of 27/11/2016) is 79,034 where under-trial prisoners are 59,732 and convicted prisoners are 19,302 while the capacity of these prisons is only for 36,614 prisoners (Bangladesh Prison 2016).

Recurrent Engrossment of Islamic Militancy: There is a quick growth of Islamic militant groups in Bangladesh for over a decade. Although law enforcement authority sent many of them for trial, the growth is in its due course. At the early stages, only the people of religious institutions who formed extremist groups were engaged in radicalism. Recently it has been found that educated young minds have been radicalized and betrothed to create fear-provoking environment in the country as part of their interventions.

Militants out of Prisons on Bailt Some 800 militant suspects arrested in anti-militant drives in the last five years (up to April 2016) have secured bail from different courts. Most of them were members of banned militant outfits such as JMB, Ansarullah Bangla Team and Hizbut Tahrir. After getting released on bail, they were allegedly carrying out gruesome attacks in different parts of the country. This refers to weak investigation, slow trial' (Daily Sun 2016).

Lax Surveillance over militants: According to a report published in a daily newspaper about an intelligence report submitted to the Ministry of Home Affairs, the accused militants, who subscribe to similar ideologies, manage to communicate with one another through various means since they have been staying in the same jail for quite a long time. The identities of the persons, who meet the militants claiming to be family members, are not properly verified. The report showed, "Gaining unfair advantages, the militants are keeping their networks operational beyond the prison walls." It means that prison walls are failing to contain a thriving terror web as militants behind bars apparently take advantage of lax surveillance to discuss ideas 
and make plans and keep their networks operational outside through visitors. There are over a hundred accused militants in Kashimpur jail. Of them, more than 50 remain in the high-security unit (Daily Star 2016).

Lack of Policy Transformation: Prisons in Bangladesh are managed following Jail Code which consists of Prisons Act 1894, Prisoners Act 1900, Identification of Prisoners Act 1920, Rules made under Section 59 of the Prisons Act 1894 and Rules made under Section 60(a) of the said Act of 1894. This system has not been upgraded though we had farsighted recommendations for prison reform made by the Jail Reform Commission in 1980.

\section{Rehabilitation and Deradicalization in Bangladesh}

The concept of rehabilitation is not explicitly mentioned in the constitution of Bangladesh. The essence of some articles can be extended to cover the rehabilitation issue, such as in article 14 and 35(1). Volume I (Part I) of the Bangladesh Jail Code Rules for the Superintendence and Management of Jails in Bangladesh (Revised edition 2006) mentioned the word - "rehabilitation" at least 11 times. First and foremost, it needs to grow the consensus that "Hate the wrong, not the wrongdoer" that might contribute to rehabilitation works where punishment fails. The rehabilitation of prisoners and ex-prisoners is a relatively new topic in Bangladesh, but one that is very close to the heart of Brigadier General Syed Iftekhar Uddin, the Inspector General of Prisons. As he explains, a significant number of ex-prisoners re-engage in criminal activities after they are released due to a lack of proper rehabilitation facilities and failure to reintegrate into the society' (GIZ 2016).

Some income generation skill development and education programs were taken for prisoners in Moulavibazar Central Jail. A garment factory having 26 knitting machines was established in the Dhaka Central Jail aiming towards skill development and rehabilitation of the prisoners. Bangladesh does not have any specific prison based deradicalization program (no viable information was found in the study or nothing was mentioned by any of the key informants). After 2005 a grass roots program was implemented mainly in the three regions historically known for violent extremism, recruitment to militant groups, crime and violence: Cox's Bazaar, Bogra and Sylhet. The program did not focus on rehabilitation of convicted extremists but was rather a broader-based, society-wide motivational program, targeting village madrassas, mosques, imams and religious leaders with a strong local following. 'Bangladesh offered cash to lure militants away from terrorism' who had 'chosen a dark path' and realized their 'mistake', and surrendered'. A report revealed referring to the Chief of 
the Rapid Action Battalion-Benazir Ahmad, "If the militants want to come to the normal life, we will help them". In this regard one of the key informants of this study said,"This strategy has been undertaken in other places such as Saudi Arabia and Indonesia as well."

\section{Conclusion and Recommendations}

The key finding of the study is the existence of Bangladeshis prisons as a space of extremely high vulnerability to extremist (and Islamist) radicalization. The major reasons for this high level of vulnerability includes; over-crowding (the number of actual prisoners was found to be over double than the capacity of the prison system), de-humanization of entrants into the prison system (due to highly prevalent prisons crimes and corruption), corruption in the prison system (creating inequality in treatment of prisoners), and so on. Moreover, the study also found that the dysfunctional criminal justice system is another major reason for radicalization of prisoners. The violence which is perpetrated in the name of "remand in custody" and prosecution of innocents through the justice system creates sufficient inducement for radicalization in the prisons. In that respect, the reforms of the prison system, without a reform and operation of safeguards within the constitutional scheme and criminal justice will have very little impact in reducing radicalization in prisons.

The paper failed to find the existence of any deradicalization programs within the prison system. This is primarily because the key informants have never heard of "deradicalization". Moreover, there is no segregation of those charged and/or convicted under the anti-terrorism laws from the other prisoners. If the already radicalized elements were not identified within the prison system, it is unclear how deradicalization programs could be implemented exceptionally. However, there is a possibility that deradicalization programs are implemented as a part of other existing reform programs in the prisons. Nevertheless, the question remains, can a complex programe like deradicalization be undertaken with prison staff who have very little knowledge about it.

\section{Recommendations}

Prisons are not just a threat-prison may play a positive role in tackling problems of radicalization and terrorism in society. Hence, the prison system should continue to explore the root causes of inmate subculture, extremist interpretations of religious doctrines and how they lead to hatred and violence and the vulnerability of inmates to radicalism and launch proper deradicalization programs. Some possible ways in going about improving deradicalization programs could be by: 
- Improving and enforcing effective rules and procedures to ensure prison management and staff accountability as a way to reduce opportunities for prison radicalization;

- Attuning staff capacity and leadership in prison as a way to help address prison radicalization;

- Arranging a safe environment in prison where violent extremist radicalization can be identified early on and terrorist recruiters have less opportunity to target vulnerable individuals;

- Utilizing all legal resources for gathering information on what is happening within prison as a way to identify potential violent extremist radicalization in prison;

- Intensively monitor all forms of communication in prisons in order to detect any violent extremist radicalization, activities, plans including increasing surveillance and imposing restrictions on sending militant inmates' to courts, their meetings with outsiders and their treatment at hospitals etc.;

- Initiating rehabilitation and deradicalization effort in prison following the example of experienced countries that have already been successful;

- Conducting risk assessment in order to determine risks of prison inmates susceptibility about terrorist ideology;

- Furthering in-depth study on radicalization, prison radicalization and deradicalization in Bangladesh may be carried out with access to prison.

Finally, deradicalization programs have the potential to be of enormous benefit. Indeed, successful programs can encourage formerly dangerous individuals to stay away from terrorism and radical organizations. Innovative approaches to rehabilitation and deradicalization efforts in or out of prison should be initiated following the example of experienced countries those have already been successful in this regard. But all the time it should not be regarded as a panacea because there is a notion that "one size fits all".

\section{References}

Al-Lami, M. 2008. Studies of radicalization: State of the field report. England: University of London.

Aldoory, L. 2001. "Making health connections meaningful for women: factors that influence involvement." Journal of Public Relations Research, 13(2), 163-185. 
Alexander, Y. 1999/2000. "Terrorism in the Twenty- First Century: Threats and Responses." DePaul Business Law Journal 12(291):59-75.

Alexander, Yonah, 1992. International Terrorism: Political and Legal Documents. Dordrecht, Boston: M. Nijhoff.

Asch, S. E. 1955."Opinions and social pression." Scientific American 193, 31-35.

Asthana, N. C., and Anjali Nirmal. 2001. Terrorism, Insurgencies and Counterinsurgency Operations. Jaipur: Pointer Publishers.

AVID (General Intelligence and Security Service). 2006. Violent Jibad in the Netherlands. The Hague.

Bin Laden, others sign fatwa to 'kill Americans' everywhere. ( February 1998). Al-Quds al-Arabi.

Blanchard, C.M. 2008. Islamic religious schools, Madrasas: Background. (Order Code RS21654). Congressional research service: The library of congress. Retrieved from http:// fpc.state. gov/documents/organization/61473.pdf.

Borer, Douglas A. 2000. Superpowers Defeated: A Comparison of Vietnam and Afghanistan. London: Frank Cass Publications.

Calvert, J.2010. Sayyid Qutb and the Origins of Radical Islamism. New York: Columbia University

Cilluffo F, Saathoff G. 2006. Out of the shadows: Getting ahead of prisoner radicalization. Washington, DC, USA: Homeland Security Policy Initiative.

Daily Star. 2015. retrieved from www.dailystar,net/star-weekend/spotlight/rotting-behindbars-137293 on 19/10/2016)

Dearey M. 2010. Radicalization: The life writings of political prisoners. New York, NY, USA: Routledge.

Dwyer, J., D. Kocieniewski, D. Murphy and P. Tyre. 1994. Two seconds under the world: Terror comes to America the conspiracy behind the world trade center bombing. New York: Crown Publishers.

Enders, W. and T. Sandler. 2005. “Transnational Terrorism 1968-2000: Thresholds, Persistence and Forecasts." Southern Economic Journal, Southern Economic Association, 71(3): 467-482.

Federal Bureau of Investigation Counterterrorism Division. The radicalization process: From conversion to Jihad. Available from: http://cryptome.or/fbi-jihad.pdf (accessed on $18 / 10 / 2016)$

Fernandez, L. 2009. "Organized crime and terrorism: From the cells towards political communication, a case study." Terrorism and Political Violence 21 (4):595-616.

Guetzkow (Ed.) Groups, Leadership and Men. Pittsburgh, PA: Carnegie Press.

Gupta, R., 2004. Terrorism, communalism and other challenges to Indian security. Delhi: Kalpaz Publication. 
Hamm M. 2007. Terrorist recruitment in American correctional institutions: An exploratory study of nontraditional faith groups final report. National Institute of Justice. Available from: http://www.ncjrs.gov/pdffiles1/nij/grants/220957.pdf.

Harrigan, J. 2012."The rise of religious-based radicalism and the deradicalisation programme in Bangladesh." In El-Said, H. De-Radicalizing Islamists: Program and their Impact in Muslim Majority States. London: Routledge.

Hassan, R. 2008. Inside Muslim Minds. Melbourne: Melbourne University Press.

International Crisis Group (ICQ). 2007. Islam and identity in Germany, report Europe 181. Isma3 - listen: National consultations on eliminating prejudice against Arab and Muslim Australian.

Johnson, A., Carrell, S., \& McGirk, J. 2003. “The war on terror: Is this the first evidence of a suicide bomb plot in Britain?" Independent on Sunday.

Kabir, N. A. 2007. "Muslims in Australia: The double edge of terrorism." Journal of Ethnic and Migration Studies 33 (8), 1277-1297.

Trujillo, H. M., Jordan, J., Gutierrez, J. A., \& Gonzales-Cabrera, J. (2009). "Field research in 25 Spanish Prisons." Terrorism E Political Violence 21(4):558-579.

\section{Key Informants Interviewed}

1. Professor Dr. Ali Riaz, Chairman, Department of Politics \& Government, Illinois State University, Illinois, USA

2. Major General Abdur Rashid, Security Analyst and Executive Director, Institute of Conflict, Law \& Development Studies (ICLDS)

3. Brigadier General Shahedul Anam Khan ndc, psc (Retd), Editor, Op-Ed and Strategic Affairs, the Daily Star

4. Air Commodore Ishfaq Ilahi Choudhury, Treasurer of Asia Pacific University, Bangladesh

5. Mr. Amjad Hossain, Left Movement Activist and Former Political Inmate

6. Brigadier General Zillur Rahman (Retd.), Former Inspector General of Prisons, Government of Bangladesh

7. Barrister Muniruzzamn, Deputy Attorney General (Death Reference), Government of Bangladesh

8. Anonymous, Deputy Inspector General, Department of Prisons, Government of Bangladesh

9. Dr. Shahdeen Malik, Advocate, Supreme Court of Bangladesh

10. Prof. Dr. Mizanur Rahman, Former Chairman, National Human Rights Commission of Bangladesh. 